\title{
In memoriam Claude François Baudez. Dominar el
} tiempo

\section{(2) OpenEdition \\ Journals}

Edición electrónica

URL: http://journals.openedition.org/jsa/15286

DOI: 10.4000/jsa.15286

ISSN: 1957-7842

Editor

Société des américanistes

Referencia electrónica

"In memoriam Claude François Baudez. Dominar el tiempo », Journal de la Société des américanistes

[En línea], Maya times | 2017, Publicado el 31 diciembre 2017, consultado el 23 septiembre 2020.

URL : http://journals.openedition.org/jsa/15286 ; DOI : https://doi.org/10.4000/jsa.15286 


\title{
In memoriam Claude François Baudez
}

\author{
No cabe duda de que los mayas representan el tiempo mediante un \\ recorrido espacial; pero, además, dichos recorridos corresponden a la \\ terminación de un ciclo. \\ El rito tiene aquí por objetivo dominar el tiempo y, sobre todo, garan- \\ tizar su continuidad, al evitar las rupturas. \\ Claude F. Baudez, Una historia de la religión de los antiguos \\ mayas, UNAM, México, 2004, p. 299.
}

\section{"Dominar el tiempo"}

El coloquio internacional organizado por el Groupe d'enseignement et de recherche sur les Mayas et la Mésoamérique (GERM) y el museo del quai Branly, que se celebró a un poco más de un año de la muerte de Claude F. Baudez, nuestro colega y amigo, le fue dedicado. Una manera de dominar el tiempo, por la memoria. A su vez, esta publicación es un testimonio de nuestro respeto, admiración y amistad para él.

El trabajo académico de C. F. Baudez, amplio y diverso, animado por una constante curiosidad acerca de lo que fue Mesoamérica en su historia y cultura y en las obras artísticas que ha legado a la humanidad, es un modelo para todos nosotros. Sus contribuciones no dejan de cuestionarnos. Siguiendo caminos variados, combinando en particular la arqueología y la iconología, abrieron pistas inéditas de comprensión de las religiones mayas (Claude abogaba mucho a favor de este plural) de manera a la vez inventiva y prudente.

Apasionado por la discusión, cómplice de todos aquellos quienes interrogan la antropología, la historia y el arte, sin olvidar la arqueología, Claude se apegaba a los tres principios del grupo de colegas que había contribuido a formar: confrontación y a la vez colaboración entre disciplinas, comparaciones cercanas y más lejanas, intercambios de conocimientos y enseñanza. Durante toda su vida, transmitió, en un mismo movimiento, la inquietud y la alegría que suscitan miradas nuevas en todo trabajo científico. 